\title{
ISSUES OF THE LANGUAGE POLICY OF FAMILIES WITH UKRAINIAN ORIGIN IN THE ESTONIAN EDUCATIONAL SPACE
}

\author{
Elvira Küün
}

University of Tartu Narva College and Tallinn University

\begin{abstract}
The article addresses the family language policies of multilingual families (FLPs) with Ukrainian roots, describing, among others, the language practices of families in different areas. The analysis of the study is based on semi-structured interviews with newly arrived Ukrainian immigrants living in Tallinn. The language ideologies of families in relation to the choice of languages of education are examined. The secondary objective is to find the reasons why some families manage to maintain their national language and culture and others do not. The article shows that the desire to integrate into Estonian society has influenced the choice of language of instruction of the school among newly arrived immigrant parents, whereas, depending on different cases, the choice was both Estonian and Russian-language school. The article also shows the language management of parents of the studied families implemented with a view to maintaining their language of origin, among which, for example, participation in the Sunday school for the study of Ukrainian language and culture is also in focus alongside the language of instruction in a general education school.
\end{abstract}

Keywords: family language policy, language ideology, language practices, Sunday school, Estonian-language learning environment, Russian-language learning environment, Ukrainian language

DOI: https//doi.org/10.3176/tr.2022.1.06

Received 23 October 2021, accepted 7 January 2022, printed and available online 10 March 2022

(C) 2022 Author. This is an Open Access article distributed under the terms and conditions of the Creative Commons Attribution 4.0 International License CC BY 4.0 (http://creativecommons.org/ licenses/by/4.0). 


\section{Introduction}

Based on statistics, of the 3\% of Ukrainians living in Tallinn a relatively small percentage (1\%) use Ukrainian as their mother tongue (REL 2011). Some Ukrainians living in Tallinn and elsewhere in Estonia are newly arrived immigrants.

The definition of a newly arrived immigrant is based on the definition of "newly arrived immigrant' provided in Riigi Teataja, which means an adult person from the European Union or a third country who has lived in Estonia for up to five years (Riigi Teataja 2014). Currently, newly arrived immigrants to Estonia settle mainly in Tallinn (48\%) and Harju County (9\%), and there are also Ukrainian citizens among them (Kaldur et al. 2019). The reasons for immigration are also different from before: there are a certain number of Ukrainian war refugees alongside those who change their country of residence for better work or other economic reasons.

The article examines family language policy (FLP). In the field of FLP research, Bernard Spolsky's (2004 and 2009) model has proven to be influential, envisaging FLP to be made up of three components: language practices, language management, and language ideologies (see also Curdt-Christiansen 2018). According to Spolsky's theory (2004), family language ideology is a more general understanding of different languages and their learning, which is directly related to the perception of the need to use languages: which language is deemed the most appropriate in certain areas etc. Spolsky (2004: 5) defines language management as a means of influence to change language choices by using different types of intervention. In this article, language practice means languages used in different areas and different versions of languages, which, in addition to language ideologies developed within the family, can be directly linked to the perception of the formality of the situation, determining which language is appropriate to use (ibid.).

As language ideologies can be seen in the context of self-determination, the article also addresses the aspects of the dynamism of ethnic identity and even the emergence of competing identities (see also Seals 2019). In other words, the article relies on the definition of ethnic identity where it is not necessarily seen as something static but instead as a phenomenon that may renew over time according to changing circumstances (e.g. migration) (Liebscher and Dailey-O'Cain 2013), also in relation to the language and educational space. The reader can find examples of the respective approach in subsection 5.3.

The objectives of the study on which this article is based are the following: 1) to study which factors have influenced the decision of language managers in the choice of language of education; 2) to determine whether the choice of language of education targets the language practices of both the parents and their children; 3 ) to determine which factors encourage some families to maintain the language and culture of their ethnic minority while not all families succeed in doing so?

Based on the objectives of the study, I raised the following research questions:

- What kind of internal and external language management tools are parents of the studied families using for their children?

- Which language ideologies are the studied parents introducing to their children, incl. while making educational choices? 
- What are the opinions of parents of children studying at the Sunday School Nadija for the study of Ukrainian language and culture established in Tallinn regarding the role of the school in supporting the language policy objectives of the families?

Interviews conducted with families allow conclusions to be drawn about the language policy chosen by the language managers and considering the data received as a case study (see also e.g. Lazdina and Marten 2021). I am not, of course, claiming that the results obtained are applicable to all Estonian Ukrainians (both Ukrainian and Russian speakers). However, as with this type of research, I can provide detailed knowledge of which language ideologies represent the language choices made in the families of language managers.

First, an overview of the definitions concerning FLP is provided, and it is also associated with the aspect of maintaining identity. Among others, the study focuses on the emotional experiences of adapting to the new environment and if and how language practices of Ukrainian families are influenced by Estonian and Russianlanguage basic education and Ukrainian-language hobby education. The empirical part of the article describes the language practices, language management and language ideologies of each language manager's family. The article ends with a discussion and a summary.

\section{The peculiarity of family language policy}

FLP is called home language planning in the home environment, which may in some cases be subconscious or externally hidden (see also Curdt-Christiansen 2009 and 2018, King et al. 2008, Soler and Zabrodskaja 2017, Verschik and Doyle 2017). In general, there is currently a trend in the field of FLP research where a greater emphasis is put on the general background of families and the interplay between decisions made in the family and the expectations of society (see e.g. Higgins 2018). I have taken this approach to FLP as a basis.

It should be added, however, that in the field of FLP, as a recent research trend, the emotions and opinions of children and teenagers towards the FLP implemented by their parents have started to be taken into account (see e.g. Wilson 2019 and 2020). However, it is important to note that while some FLP researchers (e.g. Fogle and King 2013, Kopeliovitch 2013, Palviainen and Boyd 2013, Verschik and Doyle 2017, Wilson 2019 and 2020) have approached FLP through the cognition prism of a child or an adolescent, FLP research has so far mostly focused only on the endeavours and desires of adults (Schwartz 2010, Wilson 2020). To date, little research has been done on bilingual or multilingual school-age adolescents whose sociolinguistic environment reduces the use of a heritage language in connection with enrolment in a general education school (Rothman 2009). Sonia Wilson has rightly pointed out that in the field of FLP, the focus of research should also include the children's own views on the perception of bilingualism and plurilingualism in their family in order 
to develop an integrated approach to aspects related to FLP (Wilson 2020).

It has been determined that the flexibility of parents in establishing language ideologies is a very important criterion as a whole in perceiving FLP as positive both for the parents and for the children themselves (Kopeliovitch 2013, Soler and Zabrodskaja 2017). More information on how children themselves perceive the FLP established in the family could help, if necessary, the family in directing their language ideologies (Wilson 2020), among others, making corrections, as also indicated by the results of the study serving as a basis for this article.

As FLP can be influenced by many factors, the potential changes in the FLP determine its dynamic nature (see Curdt-Christiansen 2018). By extending the aforementioned FLP model of Spolsky (2004 and 2009), other, improved FLP frameworks can be created based on different emphases (Curdt-Christiansen 2018, Lazdina and Marten 2021, Wilson 2020). In particular, although Spolsky himself has emphasised non-linguistic factors such as the educational space surrounding the children as the influencer of the language ideologies of parents in the development of FLP in addition to the three main components of FLP (Spolsky 2009), X. L. CurdtChristiansen (2018), for example, has outlined in his study that in addition to the dynamism of FLP, the sociolinguistic, socioeconomic and political circumstances of the families also have an impact. Sanita Lazdina and Heiko F. Marten (2021) who have studied similar topics in Latvia, for example, have used this expanded FLP model as a basis for their research. Although as the author of the article, I agree that FLP involves many aspects, I am still of the opinion that the core of FLP can indeed be reduced to the three components of FLP proposed by Spolsky (2004 and 2009). As such, I have used these as key aspects in answering the research questions.

However, it is important to note that introducing FLP in the family may still be quite problematic in some cases. It is certainly not possible to say that all children and adolescents automatically subject to the language policy established in the family. It has been found that they could very consciously also avoid using their language of origin (see also Bergroth and Palviainen 2017, Mills 2001, Tuominen 1999). Children and adolescents may also openly protest their parents' FLP (see e.g. Kaveh 2018) as was also shown in one case in this study. Therefore, it can be concluded that children are far from always being in the role of passive recipients of the language ideologies of their parents. Moreover, children have also been seen as intermediaries of FLP, i.e. important developers of FLP (see e.g. Smith-Christmas 2020).

It has been observed that relaxing the boundaries of rigid language practices at home provides children with a minority language background a better opportunity for shaping their cultural identity (Wilson 2020). In reality, there is no clear rule or guarantee that the language practices, ideologies or a cultural identity of the members of a family should necessarily overlap (see e.g. Czubinska 2017, Duff 2015), especially considering the migration history of migrant families (CurdtChristiansen and Huang 2020), the language policy of the country of destination, and the internal intentions, including in relation to the identity, of immigrants. The author of the article agrees with the opinion of Andrée Tabouret-Keller (2000) that everyone has the right to construct their own identity, for example by creating new, 
among others, hybrid identities through different language practices (see also Padilla and Perez 2003).

It is only natural that the dynamism of parents' language ideologies is also influenced, among others, by the greatest possible educational success that parents hope for their children in the country of destination (Curdt-Christiansen 2009). At the same time, parents often take into account the perception of their ethnic identity and giving meaning to it in maintaining or reshaping their linguistic beliefs (ibid.). However, I would like to emphasise that in the case of children newly arrived in Estonia from Ukraine, it is important to also take into consideration the effect of the language and cultural space of schools on the sense of ethnic identity among adolescents still developing.

\subsection{Relationship between the educational environment and identity}

Language policy changed in the new social order that emerged after 1991, and it has had a certain effect on the language and school choices of individuals. For example, while in the 1990s, the participation of Russian-speaking students in a state-language school was still a new phenomenon in the Baltics (see also Lazdina, and Marten 2021), almost 30 years later, this tendency has become the so-called new normal. A similar trend where newly arrived immigrants enrol their children in schools with Estonian language of instruction upon arrival in Estonia can be seen today both among Russian-speaking and other non-Estonian-speaking newly arrived immigrants (see e.g. Kond 2016). In choosing a school for their children based on the language of instruction, parents are usually guided in their decision-making by pragmatic aspects, primarily by economic reasons (Lazdina and Marten 2021) where acquiring the majority language at a very high level and in a natural environment is an important aspect.

Although the results of several studies (see e.g. Curdt-Christiansen 2009, Tseng 2020) confirm the preservation of one's own ethnocultural identity as a motive for ensuring the continuity of their language of origin among national minorities, the relationship between valuing one's own language and (not) using the language is not always one to one (Bilaniuk and Melnyk 2008). For example, the language of origin may be treated with respect while not being used (ibid.). This tendency where ethnolinguistic boundaries do not always coincide is indeed striking in Ukraine (Verschik 2010). It has been noted that, in connection with the language policy of the former Soviet regime, a significant gap was created in Ukraine between ethnocultural identity and the actual language practice, which subsequent political events in Ukraine have only exacerbated even further (Kulyk 2016). According to the study on which this article is based, some language managers also mentioned the impact of the language policy at the time on the educational space. Although the status of the Ukrainian language has risen in the independent Ukraine, the number of Ukrainian speakers has not increased significantly (see Bilaniuk and Melnyk 2008). However, the rate of use of Russian has undergone a change in some parts of Ukraine as well as in education (Pavlenko 2011). When analysing the results of FLP studies, 
it is important to keep in mind that attitudes towards one's own language of origin may significantly differ in the families of students of national minorities (Rannut and Rannut 2010).

\section{Research methodology}

In the study on which the article is based, a questionnaire developed for studying plurilingual families in an adapted format as an interview framework is used. The author has obtained the permission to use it from professor Anastassia Zabrodskaja at the Tallinn University who is responsible for the project 'Globalization and family and social plurilingualism in medium-sized language communities (MSLC) in Europe' (GLOBLINMED) in Estonia. ${ }^{1}$ I have supplemented the interview framework by adding questions concerning the attendance of Sunday school by the children of the studied families and the level of proficiency in Ukrainian. In addition, I asked the language managers about the use of Ukrainian symbols as one of the hinges of identity in today's home environment.

I believe that a semi-structured interview has allowed to get an optimal amount of data through a freer use of the interview framework and added naturalness to the communication, allowing the interviews to be conducted as freely as possible (see also Laherand 2008). The fact that language managers participated in the interviews in their home environment (albeit using a smart device) also suggests that this made the interviews conducted for the study both more stress-free and comfortable for them. In addition, the article takes into account the principles of a case study, which allows the study objects to be registered at a specific point in time (Yin 2009). The method also allows analysing the phenomena through the eyes of the interviewees (Peräkylä 2005).

The interviews with language managers took place in April 2021, and the data collected have been examined in more detail using targeted qualitative content analysis (Kalmus et al. 2015). In other words, data analysis is based on the main content aspects of the text material important for answering research questions (ibid.).

I got in touch with the language managers through the head of the Ukrainian Expatriate Community Sunday School Nadija. First, I contacted the head of the school over the phone, explaining the principles of the study. She found if there was anybody interested in participating in the study who would qualify as the target group. An interview framework had been sent to the head of the school by e-mail for this purpose. Further communication took place at an agreed time individually with each language managers who had agreed to participate in the study.

Given the emergency situation established in Estonia in the spring of 2021 (coronavirus restrictions had not yet been relaxed), the interviews took place as video interviews (through the virtual environment Viber) at the request of the language managers. I recorded the interviews using a voice recorder and transcribed

1 Tallinn University research and development project TRU15044 in 2014-2015 (FFI2012-35502). 
them by hand. Verbatim transcription has been used as transcription strategy, i.e. the text has been transcribed word for word without the use of transcription marks (see Linno 2021). More specifically, unfocused transcription has been chosen in the study serving as the basis for the article because the level of detail of transcription depends on the analytic strategy (ibid.). As qualitative thematic content analysis has been prepared in the study serving as the basis for the article, detailed transcription was not essential (Linno 2021). The video interviews allowed observing the facial expressions, nuances in the tone of voice as well as actual linguistic behaviour (i.e. the conformity between language ideology and language practice) of the language managers as there were situations where the language managers addressed their child for a moment during the interview. There were some technical issues with the third interview of this study (i.e. there were no audio interruptions, but video image disappeared for a time). Nevertheless, the video interviews served their purpose they can be used to successfully answer the research questions posed in the article.

As the coronavirus restrictions relaxed, i.e. a couple of months after the video interviews, the author of the article visited the Sunday School Nadija (in June 2021). ${ }^{2}$ Both the school's studies and school landscape were examined on location.

The author of the article used Russian as the common language of all participants both in conducting the interviews with language managers as well as in the interactions with the head of the Sunday school and the teachers, because the author is not proficient in Ukrainian. It should be noted that although not part of the Ukrainian community, I allege that the conditions for maintaining the language and identity of Ukrainians has been little studied in Estonia (see e.g. Küün 2021) and the relevant issues, therefore, need further consideration and discussion also in the context of the Estonian education policy.

\section{Sampling principles}

A purposeful sample has been applied in the study on which this article is based, i.e. language managers have been included in the sample based on a content criterion that meets the requirements (Õnapuu 2014: 150), i.e. the language managers from each studied family are of Ukrainian origin and have either studied at Sunday School Nadija for the study of Ukrainian language and culture operating in Tallinn themselves or have enrolled their children to study there. I asked all the language managers for their consent to participate in the study, in the interviews, and to have the conversations recorded using a voice recorder.

To ensure anonymity, the interviewees are referenced and excerpts from interviews are presented using pseudonyms. The current study complies with research ethics, explaining to the language managers the objectives of the study, keeping the data obtained confidential, and using the data collected only for the purposes of the study (Code of Ethics of Estonian Researchers 2002).

2 As the author of the article, I would like to thank the co-supervisor of my doctoral thesis, Professor Anna Verschik of Tallinn University, who kindly agreed to assist me with her Ukrainian skills in accompanying me to the Sunday School Nadija. 
It is important to add that a total of six language managers were interviewed. The school head (A) who also teaches handicraft provided general information about the background and studies of the school. The conversation also included the teacher of the Ukrainian folk instrument bandura and of the Ukrainian folk song (B) who, apart from working at Nadija, is currently working at a Ukrainian-language kindergarten, and the teacher of Ukrainian language and culture (C). In families, which are indicated by the letter F (F1, F2, F3, respectively), three women (W1, W2, and W3), representing their families, respectively, were interviewed to study the language ideologies, language practices and language management implemented. The average length of the interviews was 43 minutes. All language managers (W1, W2, and W3) also provided information on the language practices of other members of their family and other language aspects important for the study.

\subsection{Ukrainian Expatriate Community Sunday School Nadija}

The author of the article visited Sunday School Nadija on 5 June 2021 when the children had a school day and practiced for their performance at the international festival 'Квіти України' (Ukrainian Flowers) taking place on 19 June. Prior permission for observing the classes and taking photographs had been obtained from the head of the school and parents of children who attended the Sunday school that day. Observing the linguistic landscape of the school, it was clear that Ukrainian was also used on the signs etc. ${ }^{3}$ The response of the teacher of Ukrainian language and culture at Sunday School Nadija (C) vividly illustrates the main objective of school.

\section{Excerpt from interview 1}

C: 'Our goal is for the children to be able to read, speak and understand Ukrainian. But if they can read, writing is no longer that difficult; those who need to will learn it. We [the teachers at Sunday School Nadija] must ensure that each child is proficient in and knows the basics.'

$\mathrm{C}$ uses as much life-like teaching in classes as possible, integrating the content of different subjects (culture, history and language studies). As an example, they highlight making pancakes as one of the national foods of Ukraine, accompanied by teaching in Ukrainian. In addition, they link it with teaching Ukrainian history and knowledge of the country (introduction to the peculiarities of different regions of Ukraine), explaining how pancakes are served in different regions of Ukraine, e.g. with fish in one region, with curd in another, etc. C's aim is that, in addition to factual knowledge, the students acquire as many new Ukrainian words and expressions as possible precisely though the activities.

Studies also involve cooperation with Ukrainians living in Finland, Latvia, Canada and Chicago, whereas students from different countries share their work as part of their studies, for example, videos made as a result of specific tasks. According

3 I would like to thank the head of the Sunday School Nadija for the warm welcome and the teachers and language managers for their cooperation. 
to the teachers, contacts with Ukraine are also being maintained. The teachers admit that although it has been much more difficult to organise events in the context of the coronavirus crisis, they will continue to make efforts to participate in various international competitions and field trips in the future. Parents with roots in different regions of Ukraine also help to diversify the studies. They share their experiences of culture with the teachers as there are some differences in various parts of Ukraine.

Although it was clear when observing the classes that the teachers interacted with the students exclusively in Ukrainian, the children spoke Russian with each other in the school premises, and this was also pointed out by A, adding that, in general, their students speak Russian when communicating with their parents at home. Indeed, children communicated with the parents who had come by in Russian.

Recent research has also shown that despite the children not always outright rejecting their parents' language management and language practices, they might not stay within the frames in their actual language practices, for example, creating their own language practices or simply keeping languages separate in different situations (Wilson 2020). They might not always subject to the language ideology of their parents or their teachers, for example, always using Ukrainian with one or both parents in the home environment or with teachers at the Sunday school.

\subsection{Introduction to F1}

F1 consists of only the language managers and her husband. W1 was 26 years old at the time of the interview and called herself 'Russian-Ukrainian' without further thought (W1's mother is Ukrainian and father is Russian). She considers both Russian and Ukrainian as her mother tongues, and both languages were also spoken in her childhood home. W1 has Estonian citizenship and she works in Tallinn. She was also born in Tallinn, although it was revealed that after her parents were married, they moved to Ukraine for a few years and moved back to Tallinn in 1999 when the language managers was 4-5 years old. As a reason for moving back, W1 said that 'we had my grandmother and grandmother from my father's side here'. While living in Estonia, she attended a kindergarten with Estonian language of instruction and an Estonian language immersion class since grade 1 .

W1's mother is from the Cherkasy Oblast in Central Ukraine. W1's maternal grandparents in Ukraine who are no longer alive were also from Central Ukraine, specifically from Rostov. W1's father is from Estonia and is Russian by nationality. W1's paternal grandparents are still living in Estonia. W1, who has acquired higher education in Estonia, is fairly certain that she wants to tie her future to Tallinn.

\subsection{Introduction to $F 2$}

The language manager W2 was born near Vinnytsia in Central Ukraine, she has Ukrainian citizenship and she was 45 years of age at the time of the interview. When asked what nationality she considers herself to be, W1 answered, 'I am Ukrainian by blood'. She also called her husband who is her compatriot and who lived in W2's birthplace a Ukrainian. In addition, W2 emphasised, that she is an ardent patriot of 
Ukraine and considers her birthplace Cherkasy the most beautiful place. W2 did not hesitate to say that her mother tongue is Ukrainian. The interview revealed that W2 has lived the majority of her life in and around Kiev where the Russian-language environment dominates (see e.g. Seals 2019). According to W2, she has consciously chosen the Russian-speaking district of Lasnamäe as her place of residence in Tallinn so that her daughter would also find it easier to adjust to the new environment as her daughter already spoke Russian while living in Ukraine.

She calls her family consisting of W2's husband and 10-year-old daughter 'vagabonds' because their family has had to move a lot. She considers her real home to be her father's home in Ukraine where only W2's 65-year-old mother now lives alone.

According to W2, her husband's move to Estonia was related to the war in Ukraine as general mobilisation was going on and W2 did not want her family to get caught up in the war. Thus, the interview revealed that W2's family are Ukrainian war refugees. W2 has graduated from the Vinnytsia National Technical University with a speciality in energy and is currently working in the field of cleaning services in Tallinn.

F2 lives in Tallinn, but the whole family did not settle in Estonia at the same time. Initially, W2's husband was working in Tallinn for three years while W2 was living in Ukraine. Finally, in 2019, they made the decision to reunite and W2 came to live in Estonia with her husband. F2's daughter moved to Estonia in 2020 (W2 moved to Estonia to be with her husband exactly a year earlier) because due to the spread of the coronavirus and other obstacles, it was difficult for W2's daughter to move to Estonia. During the intervening year, W2's daughter lived in Ukraine with W2's mother (or the daughter's grandmother). W2's husband had been living in Estonia for nearly 5 years at the time of the interview. In other words, F2's family is a family of newly arrived immigrants.

\subsection{Introduction to F3}

F3's language manager (W3) comes from the Donetsk district in the Donbas region in Ukraine, which is mostly a Russian-speaking area (see e.g. Seals 2019). W3's father is also from there. After a short pause, W3 defines her nationality as 'Ukrainian, really'.

W3 has Ukrainian citizenship and she was 36 years old at the time of the interview. W3 moved to Estonia in 2016, so she was categorised as a newly arrived immigrant at the time of the study. F3's family consists of five members. The family has three sons, the oldest of whom was 13 years old at the time of the study, the middle son was graduating from the 1st grade of a school with Estonian language of instruction, and the youngest son was 6 years old. W3's husband had moved to the Estonian capital half a year before his wife.

W3 has a double higher education acquired in Ukraine: first in economics and the second in pedagogy. She is currently working as a teacher's assistant in Tallinn in a kindergarten with Estonian language of instruction. W3 has been actively studying Estonian for several years. She emphasises that she would like to learn Estonian quickly.

As a child, Russian was used more in W3's home environment, although W3 admits that Ukrainian words did appear in conversations ('Yes, we speak Russian 
in Donbas, but Ukrainian words do sneak in'). When the family visited their grandmother living near the Crimea, they spoke Surzhyk as the common language variant in the area according to W3. She specifies that 'with grandmother, this Surzhyk was more like Ukrainian'. According to L. Bilaniuk, Surzhyk, in other words a mix of Ukrainian and Russian languages, differing from standard Russian and Ukrainian, is fairly widely used in Ukraine, although it is not considered a socalled proper language (Bilaniuk 2005). Perhaps this is why people are not always keen to admit that they ordinarily use this language variant in their daily lives (which, of course, cannot be said in the case of W3). At present, F3 mostly uses Russian, but W3 emphasises that her family members now also use Surzhyk from time to time when living in Tallinn. Surzhyk is generally used in informal communication situations (Seals 2019). During her acquaintance with her future husband in Donbas, they initially used Russian exclusively, so the language choices in the family have changed over time. As F3 has decided to enrol their children in schools with Estonian language of instruction and the youngest son in an Estonian kindergarten for faster adjustment to Estonian society, the use of Estonian has also sometimes appeared in conversations between the eldest son and mother, for example.

W3 has worked as a teacher in Ukraine, using Ukrainian as her working language. In Ukraine, she acquired general education in Russian (although, according to W3, 'official documents were in Ukrainian') and she emphasised that during her studies, Ukraine was starting to transition to Ukrainian as the official language.

As W3 pointed out that 'it's still mostly the fault of the war that we [F3] had to change our country of residence', it could mean that the family has had to leave Ukraine primarily because of the war. Thus, it can be concluded that F3 are also war refugees who still officially qualified as newly arrived immigrants at the time of the study. Table 1 summarises information on the background of language managers who participated in the study.

Table 1. General information of language managers of Sunday School Nadija

\begin{tabular}{lcccccc}
\hline Family & $\begin{array}{c}\text { Language } \\
\text { managers }\end{array}$ & Age & Education & Children & $\begin{array}{c}\text { Nationality by self- } \\
\text { determination }\end{array}$ & Mother tongue \\
\hline F1 & W1 & 26 & $\begin{array}{c}\text { Higher } \\
\text { education }\end{array}$ & None & $\begin{array}{c}\text { Russian/ } \\
\text { Ukrainian }\end{array}$ & $\begin{array}{c}\text { Russian and } \\
\text { Ukrainian }\end{array}$ \\
F2 & W2 & 45 & $\begin{array}{c}\text { Higher } \\
\text { education }\end{array}$ & $\begin{array}{c}\text { Daughter } \\
(10 \text { y.o. })\end{array}$ & Ukrainian & Ukrainian \\
F3 & W3 & 36 & $\begin{array}{c}\text { Double } \\
\text { higher } \\
\text { education }\end{array}$ & $\begin{array}{c}3 \text { sons } \\
(6,8, \text { and } \\
13 \text { y.o. })\end{array}$ & Ukrainian & Surzhyk \\
\hline
\end{tabular}




\section{Results}

\subsection{Fl's language practices and language management}

From the beginning of the first interview, the interviewer's attention was caught by the fact that W1 defined herself as belonging to two nationalities ('RussianUkrainian'). Given that the answer to the question about nationality came very quickly and resolutely, it can be assumed that $\mathrm{W} 1$ has come to very clearly realize her national and therefore also cultural identity and perceives a sense of belonging to both nationalities. Among other aspects, her father's nationality has probably also influenced W1's perception of national identity. W1 also named two languages Russian and Ukrainian - as her mother tongues. In her childhood home, W1 had communicated with her mother in Ukrainian and Russian and with her father in Russian, and that had remained the same for them over time. According to W1, such a choice of language was consciously developed in the family because father did not speak Ukrainian, while mother found it easier to communicate precisely in Ukrainian.

W1 and her husband live separately from the parents, and the use of Russian dominates in her home. W1 has noticed in her group of friends and in interacting with the members of the Baptist congregation that although there are people of different nationalities (e.g. Russians, Belarusians, Ukrainians) among her congregation, Russian is still mostly used in communication. However, W1 adds that 'there are a couple of people among my acquaintances through church with whom I communicate in Ukrainian, they are from Ukraine'.

In the interview, W1 points out another important aspect, which leads her and her husband's language use towards Ukrainian. That is, when they visit Ukraine (usually once or twice a year), their speech becomes 'more Ukrainian by itself'. Thus, as the country and the linguistic environment change, so does the language use of W1 and her husband. However, it is fascinating that, as W1 mentions, her husband may have a few Ukrainian words and expressions creep into conversations in their Tallinn home too, and, according to W1, her husband does not even notice it himself. According to W1, her husband could sometimes also integrate Ukrainian words into Russian speech. W1 calls it a mixed language characteristic of her husband. Thus, in view of this information, it can be thus said that W1's husband uses both Russian as well as Surzhyk depending on the language environment.

At the same time, W1 claims that she herself keeps languages separate and does not use code-switching or alternation in her speech. However, the information obtained during the interview does not confirm this (at least, this is not the case with the use of Estonian and Russian). W1 admits that outside home, more specifically at work, her language choices and 'even thinking' have become more and more influenced by Estonian because it is her working language. Indeed, throughout the interview, W1 uses Estonian terms or terms containing Estonian-Russian code-switching (mostly related to education) in her Russian speech.

During the interview, it turns out that $\mathrm{W} 1$ considers herself a trilingual person and it is convenient and easy for her to communicate in Russian, Ukrainian and 
Estonian alike. She prefers to use Russian as reading language and Estonian in her working environment. At the same time, she adds that in Ukraine or elsewhere where Ukrainian is spoken, she smoothly switches over to Ukrainian because, according to $\mathrm{W} 1$, it is more natural for her to use Ukrainian in these situations. W1 notes that for her the choice of language depends on the people she is communicating with, as well as on how the language of communication with this person has developed. In other words, W1 uses an area-specific and partner-based principle of language choice in her communication.

As media languages, W1 mostly uses Russian and Estonian, and she also reads information in social networks in Ukrainian. F1 has no cable television. N1 and her husband watch shorter shows mostly on youtube.com and movies on Netflix. W1 keeps up to date with the news on the Internet, reading the Estonian newspaper Postimees in both Russian and Estonian.

Regarding the family language management implemented in W1's childhood, it should be mentioned that mother used Ukrainian and Russian when speaking to W1, sang Ukrainian lullabies and read books in Ukrainian (also in Russian). W1 singled out that while her family was living in Ukraine, she would constantly speak to her mother in Ukrainian, but after moving back to Estonia - W1 was either 4 or 5 years old at the time according to her recollections - the use of Russian increased in the family in connection with the change of environment. As external language management tool, W1's parents enrolled her in a kindergarten with Estonian language of instruction at first when returning to Estonia in 1999 and then in a class offering early Estonian language immersion. During school holidays, W1 could practice Ukrainian when visiting relatives in Ukraine. In addition, W1's parents decided to enrol their daughter in Sunday School Nadija for the study of Ukrainian language and culture. According to W1, the following circumstances motivated W1's mother to enrol her in the school.

\section{Excerpt from interview 2}

W1: 'I think my mother missed Ukraine... and Ukrainian culture, she was looking for somewhere she could speak in Ukrainian. She wanted me to know Ukrainian songs, traditions, Ukrainian history. [ _ _ I I associate certain customs with certain traditions and know their background thanks to Nadija [ _ _ ] yes, school [Sunday School Nadija] has certainly contributed to me becoming more aware of my Ukrainian roots growing up.'

This excerpt from the interview indicates that studying at Sunday School Nadija has helped W1 to better understand what is happening around her in a cultural sense and delve into the essence of old national traditions.

Although W1 wants her future children to be able to speak very good Russian, Estonian and Ukrainian, she predicts that Russian will become their home language. As a reason, she indicates the fact that the use of Russian has already become a habit in the communication between W1 and her husband and it is the most convenient option for both of them. 
To conclude the interview, W1 encourages bilingual and plurilingual families to speak in different languages. She has developed her opinion on this issue based on personal experience. She is sure that children will not confuse languages used in the family. Based on her own example she claims that children will not be afraid to use different languages in the future and language use can open quite a few doors to the child as an adult that might stay closed if they are not proficient. W1 believes in the usefulness of the 'one parent - one language' (OPOL) communication strategy and, indeed, several authors (see e.g. Piller 2001, Schwartz 2010) have indicated the success of the OPOL strategy in implementing FLP. At the same time, for example, Annick De Houwer has written about how the OPOL strategy does not always ensure the continuity of the minority language of origin in the family (De Houwer 2009). As already mentioned above in addressing theoretical approaches, FLP that is flexible by nature is considered even more effective (see e.g. Kopeliovitch 2013, Soler and Zabrodskaja 2017).

\subsection{F2's language practices and language management}

W2's nationality is Ukrainian by self-determination. She says that Ukrainian is her mother tongue, and she has been using it with her husband since they met. Although communication in Russian is not the slightest effort for W2, she says that because most of the period of her studies has been in Ukrainian ('my studies fell at a time when Russian was already politically condemned'), there could be some grammar mistakes in her Russian. At the same time, according to her, the people living in Central Ukraine and in W2's hometown are mostly Russian-speaking and because she has also always had to use Russian in her later career, communication in Russian is also very natural to W2. She has lived most of her life near Kiev. Because, as already mentioned above, it is one of the Russian-speaking areas of Ukraine (Seals 2019), it is also understandable why communication in Russian has been very important to W2 in her daily life and at work. At the same time, W2 says that when it comes to language choice, where and with whom she is communicating is very important to her. For example, Ukrainian is increasingly common in rural areas, given also the abundance of dialects (see e.g. Seals 2019) and, in this case, W2's language choice in communicating with relatives living there also changes in favour of Ukrainian.

In her home environment, W2 has not consistently demanded her daughter to use Ukrainian. On the other hand, W2's husband has entirely different principles for using Ukrainian in the home environment in communicating with his daughter: he demands his daughter to use Ukrainian at home. However, the daughter resists these demands because it is more convenient for her to use Russian when living in Tallinn. This is not surprising given that with the change of residence in 2020, her language environment also changed and, according to W2, the 'daughter has even started thinking in Russian, no longer in Ukrainian'. F2 used Ukrainian in their mutual communication before arriving in Estonia. As can be seen from the data, subsequent changes related to the change of environment have changed F2's 
language preferences and the following excerpt from the interview illustrates W2's daughter's recent defiance against the use of Ukrainian.

\section{Excerpt from interview 3}

W2: 'Although my daughter was interacting with Russian children already in the kindergarten, as she started going to school, she still studied in Ukrainian in the first grades, she spoke Ukrainian and we all constantly spoke Ukrainian at home. [ _ _ ] And the school required parents to talk to their children in Ukrainian at home to help the students understand the learning material. And my daughter can write and read in Ukrainian. But relocating to Tallinn... exactly one year ago [daughter's name] joined us in Tallinn... there were three new languages for the child... Russian... well, it's not a new language, of course, but still... and then English that she didn't know well yet, plus Estonian, which was completely new... and now she categorically refuses to speak in Ukrainian. She ONLY [emphasises] speaks Russian.'

Indeed, there is some evidence from the past that children from bilingual or multilingual families have started to avoid using the minority language in their home environment after attending general education schools (see e.g. Kaveh 2018, Mills 2004). It is possible that W2's daughter has developed defiance against using Ukrainian also because of her father's demands. It is also not impossible that F2's daughter does not consciously want to be different from the majority in her school and class and feel like a foreigner. In this case, it is possible that avoiding Ukrainian is a kind of strategy for W2's daughter to faster adjust to the Russian micro language environment in Estonia, constituting the school with Russian language of instruction and Russian-speaking classmates. The researcher was also able to ascertain during the interview that W2 uses Russian in speaking to her daughter as W2 addressed her daughter a couple of times.

However, W2 notes that the first year of adjustment in Estonia has been rather difficult for her daughter linguistically as she has taken up learning English and Estonian at the same time. According to W2, this is the reason why she opted against imposing Ukrainian on her child as a home language. According to W2, she is very satisfied that her child's educational success has in a Russian school in Estonia remained at the same good level as when living in Ukraine. The fact that there have been several fundamental changes in the life of F2's daughter over the past year, including the addition of new languages, might also be the reason why W2 has decided against imposing the use of Ukrainian in communication with her daughter and to use Russian instead.

Regarding internal language management tool, W2 informed the researcher that she used to sing Ukrainian lullabies and other songs from songbooks in Ukrainian to her daughter. The most important method of internal management tool was speaking with the daughter in Ukrainian within the family from birth, which was implemented by W2, her husband as well as W2's mother, i.e. the daughter's grandmother. Because, as W2 mentioned during the interview, her mother strictly spoke Ukrainian 
when communicating with her granddaughter, it can be used to draw conclusions on how strong the continuous Ukrainian-language input was that the daughter received within this one year before moving to Estonia. In addition, F2 has consistently and strictly required their daughter to read in Ukrainian to develop her reading speed. Before starting school with Russian language of instruction in Estonia, F2's parents prepared their daughter for school during the summer holidays, having her read books in Russian so that the child would not run into problems with grammar when writing in Russian.

As extra-familial language management, W2 mentioned sending her daughter to her grandmother in Ukraine in the summer of 2021 to use her mother's help in encouraging the child to use Ukrainian. W2 wants her daughter to be in a completely Ukrainian-language environment from time to time, and she believes that her mother will be helpful in ensuring the continuity of Ukrainian because her daughter's grandmother does not use Russian at all.

F2 also implements their family language policy through the Sunday School Nadija operating in Tallinn where their daughter can further advance her proficiency in Ukrainian and gain cultural knowledge about Ukraine. However, studying at the Sunday school has not had an effect on F2's home language use. The answer to the question what influenced F2's desire to enrol their daughter at Sunday School Nadija shows, above all, longing for Ukraine and the desire to continue passing on cultural knowledge about Ukraine.

\section{Excerpt from interview 4}

N2: 'We really miss our homeland and we suffer from being isolated from our country. I was looking specifically for this school; and, you know, it was actually our grandmother that found the school Nadija! [ _ _ _ I am very happy and glad because I found what I was looking for. She gets from the school [Nadija] what I'm not able to give her.'

Living in Estonia, W2 has broadened and strengthened her circle of acquaintances largely thanks to Sunday School Nadija, finding Ukrainian-speaking family friends (W2 calls it 'their Ukrainian-speaking community'). From time to time, they organise smaller meetings outside the school too and use Ukrainian in communicating with each other. Indeed, it can be presumed in the case of Tallinn as a capital of Estonia and a multi-ethnic city with a significant number of Ukrainians (see e.g. Kaldur et al. 2019) that a community of compatriots is formed, in communicating with whom one's own language can be used, which is not typically heard or spoken in daily and work situations, and common cultural-historic background and memories can be shared.

W2 answered the researcher's question about what F2 is using in media consumption that she did not watch TV at all due to lack of time. The family uses the Internet to communicate with W2's relatives and friends in Ukraine and to listen to the radio, F2's daughter uses a smart device to watch animated films of her choice in various languages. W2 loves to listen to Ukrainian-language music using 
headphones at work. F2's father listens to Ukrainian-language news on the radio and if W2 wants to learn something about the news, she asks her husband about the events. W2 points out that because outside the home, her family lives in a Russianspeaking environment in Tallinn, she sometimes reads news in Russian.

W2 describes her family's language ideology as follows. She considers it very important for bilingual and plurilingual families that the children of the family are able to choose themselves in which language they want to and consider necessary to communicate. According to W2, parents of this type of family must accept and respect their children's language choices, and W2 emphasises that it must be accepted even if the language choices of the family's children are unexpected and (at least initially) disagreeable for the parents. Therefore, W2 considers it important that language ideologies of bilingual and plurilingual families are flexible.

During the interview, the researcher is struck by an interesting fact: throughout the interview, W2 talks about living in Ukraine in the present as if she was still living there. Speaking about her job, W2 also points out that she believes that she cannot apply for a job in Estonia that would match her qualifications because she feels like she's a visitor here. It is possible that W2 has not fully decided where she would like to live in the future. At the same time, she emphasises during the interview that, at least for now, she wants to live in Estonia, 'because the conditions in Estonia are, after all, much better than in my homeland', and she wants to provide her daughter with the best opportunities possible.

All in all, W2 radiates strong longing for Ukraine. W2 is also strongly missing Ukrainian national foods and says that not all Ukrainian dishes can be made in Estonia completely authentically because, for example, 'trust me, Estonia does not sell this exact kind of lard that we have [in Ukraine].' When she gets in touch with her mother over the Internet and they start talking about lard, W2 tells her mother from time to time, 'that's it, this topic is forbidden' [laughs]. She says that talking to her mother about food is 'the soul screaming'. However, W2 emphasises that lard with garlic and borscht are the usual 'attributes' in F2 that must be served every week. W2 adds, full of emotions, that 'my soul is still at my birthplace' and 'unfortunately, I'm not able live in my homeland'. W2 talks to her mother in Ukraine for quite a long time every day, which probably helps to alleviate her homesickness. Communicating with Ukrainian compatriots living in Estonia could also lessen the feeling of isolation.

\subsection{F3's language practices and language management}

The language used in W3's home has mostly been Russian, which W3 explains by the influence of the language environment (as mentioned previously, W3 is from Donbas). W3's mother was born near Kiev in Central Ukraine. Later, however, she moved to live near Donbas and only used Ukrainian there at the beginning. According to W3, however, having lived in Donbas for a long time, her mother fell in the influence sphere of Russian and increasingly began to switch over to Russian. However, as W3 mentioned, using Ukrainian continued in the family to an extent, for example when joking or recalling moments from the past, particularly when 'one 
wanted to express oneself more clearly and emphasise something'. W3 recalled that even when her mother scolded her, she would use Ukrainian. Indeed, it has been observed that in bilingual or plurilingual families, it may often be the case that language is chosen based on emotions, e.g. one language is used to express positive feelings and another language to express negative feelings (Pavlenko 2004). Liina Tammekänd has also noted that languages and emotions can open up fairly different associations in parallel with different language connections (Tammekänd 2013).

Speaking of her former school days, W3 emphasises that although classmates would address her in Russian and instruction was in Russian, they still studied according to a Ukrainian curriculum, used Ukrainian textbooks, and official documents were in Ukrainian. As a girl, W3 participated in various hobby groups where all communication was in Russian.

Although communication with her future husband started out in Russian because, according to W3, 'Donetsk as a language environment itself causes it', she and her husband now also use Surzhyk where Russian dominates. W3's husband also tries to speak in Ukrainian at home. Although, according to W3, the father of the family can understand Ukrainian and is able to answer questions ('even then it's more Surzhyk'), continuously producing Ukrainian is difficult for her husband. Thus, it is fair to say that W3's husband has passive proficiency in Ukrainian. According to W3, the language used at home currently is mainly Russian.

However, the interview reveals that communication in Estonian plays an increasingly important role in the life of W3 and her children, who are studying in the Estonian-language environment. This statement is vividly illustrated by the following excerpt from the interview.

\section{Excerpt from interview 5}

N3: 'But now we might have some Estonian words creep into our family communication too, such as no nii (well so), tasa! (be quiet!), kohustuslik kirjandus (compulsory literature), kunst (art), laudlina (tablecloth). And my eldest child - we speak Russian-Ukrainian, but he is starting to switch over to Estonian. [__ _ And, you know, sometimes I use Estonian when speaking to my child. [_- ]. It's this loose environment at home.'

According to W3, her children have already adopted Estonian 'naturally as their own language'. At the same time, she mentions that the eldest son has had to learn Estonian, while the younger ones have acquired Estonian automatically.

W3 says that, currently, the language of communication between F3's children is an Estonian-Russian mixed language, although, according to W3, 'if they forget themselves', the children might also start speaking Ukrainian to each other. However, the children of the family prefer to sing in Ukrainian. In terms of singing lullabies, too, W3 recalled that she has sung those to her children the most in Ukrainian because, according to W3, they sound especially beautiful in Ukrainian.

Outside the home (at work), W3 also uses Estonian to some extent. As her working environment is in Estonian, her colleagues have agreed to specifically use Estonian in communication because W3's goal is to acquire Estonian as quickly as 
possible and in a natural language environment.

One way to communicate in Ukrainian outside the home for W3 is Sunday School Nadija. Over the last couple of years, she has found compatriots through the school with whom she speaks exclusively in Ukrainian. Additionally, W3 has recently expanded her social circle, finding other Ukrainian-speaking friends in Tallinn. W3 is active in the Facebook group 'Ukrainians in Estonia' whose members write to each other and meet each other in real life from time to time. According to W3, such information exchange is very useful for many as it's a way to receive and share information. Group members help one another when someone has a question or a concern.

Analysing the media languages used in F3, it turned out that F3 does not generally watch television because of lack of time. F3 usually watches Ukrainian shows (in Russian and Ukrainian) on the Internet. W3 says that when reading news about Ukraine, even if it is rare, she automatically uses Ukrainian. For the purpose of language learning, they also try to watch Estonian channels. In the course of the further interview, it is revealed that W3 reads Delfi's news both in Estonian and Russian, adding that she still finds it difficult to read magazines in Estonian. In conclusion, it turns out that there are four media languages in F3: Russian, Estonian, Ukrainian, and English.

Regarding F3's internal language management tools, W3 pointed out that all her children have been able to hear and speak Russian and Ukrainian in the family ('but more so Russian'). W3 has also read fairytales and stories written in other genres to her children in both Russian and Ukrainian. At the same time, her eldest child has read the works of the classics such as Pushkin in the original language. According to W3, Russian is still predominant as the reading language in the F3 family. After moving to Estonia, Estonian has also been added as a reading language, and an interesting fact was revealed - W3 reads the same material as her eldest son, which the school has made mandatory to the son as part of compulsory literature. In this way, W3 attempts to speed up the process of acquiring the Estonian language. F3 also reads newer literature in Ukrainian, for example friends and relatives from Ukraine send newer Ukrainian books to the family. At the same time, the interviewee's answers reveal that the advancement of oral proficiency in Ukrainian has been the priority for F3 (the children's reading language has mainly been Russian).

As external language management tools, F3 uses the help of the children's grandmother living in Ukraine with whom the children speak in Surzhyk over the Internet. While living in Ukraine, the eldest child studied at a school with Ukraine language of instruction, but in Estonia, F3 has chosen educational institutions with Estonian language of instructions because of the knowledge that 'we are living in Estonia and children simply must know Estonian'. However, in order to maintain their language and culture, F3 has enrolled their sons at the Ukrainian-language Sunday School Nadija. F3 was encouraged to make this choice by the desire for their children to not forget their language ('it's their mother tongue, after all') or culture. According to W3, she hopes for the continuity of this knowledge through the Sunday school. F3 also holds Ukrainian culture (among others, symbols and national dishes) 
in esteem in their home. At the same time, W3 consistently tells her children that despite being newly arrived immigrants, they are subject to the laws of the Estonian state and they have certain rights and obligations living in Estonia, and it makes no difference whether they like these laws or not.

W3 adds that after moving to Estonia, in her opinion, at least her eldest son definitely started to become aware of his Ukrainian roots, largely thanks to Sunday School Nadija. In addition, the interview revealed that the middle son who was studying in grade 1 in an Estonian school at the time of the interview seems to have Ukrainian and Estonian identity intertwined in a way, which could be seen, for example, in the drawings made by the son and the use of colour where he combines Ukrainian and Estonian symbols. W3 emphasises that the drawings of the eldest son show that the theme of Ukraine is always associated with something Estonian. According to W3, it could mean that her eldest son, too, feels connected to both Ukraine and Estonia, although Estonia is not his country of birth. It is also an example of the identity being a dynamic phenomenon that is interconnected with, among others, positioning oneself in different situations of communication (see e.g. Liebscher and Dailey-O'Cain 2013). According to W3, however, F3's middle son once even told his mother that he feels half-Ukrainian and half-Estonian. This indicates how quickly W3 and her two older children have switched into the Estonia life and have adjusted in Tallinn. W3's husband speaks Estonian to a certain extent but does not use Estonian in communicating with his sons. According to W3, the youngest son of F3 is not yet aware of his national identity as his self-determination has not yet developed.

\section{Discussion and summary}

According to the studied language managers, their families use the OPOL strategy and, depending on the family, different language strategies are also developed. In the F2 family, the important role of the grandmother in giving a continuous input of oral and written Ukrainian can be seen. At the same time, the daughter of the latter family (F2) is a good example of how strongly or quickly the child can switch languages when sociolinguistic circumstances change, no longer wanting to use her mother tongue within the family while living in Estonia and refusing to subject to the pressure from the father. Wilson (2020: 174) has also described research findings indicating that children may act as intermediaries in the family both in terms of the language and in implementing the FLP established by their parents where the children's language preferences are, among others, strongly influenced by their parents' style of implementing FLP (foremost the aforementioned rigidity of FLP versus tolerance). Thus, a gentle approach to FLP may encourage the development of a positive attitude of the second or third generation of national minorities towards their language and culture of origin (Smith-Christmas 2020, Wilson 2020).

As for the motives of choosing the language of instruction of a school, it can be pointed out that, according to W2, a school with Russian language of instruction was chosen for her daughter because she already had prior knowledge of Russian 
and W2 assumed that it would help her daughter to adapt in Tallinn in a school with Russian language of instruction and in the environment more quickly (F2 has chosen to live in the Russian-speaking district of Lasnamäe in Tallinn). The data show that the academic success of F2's daughter has not suffered after moving to Estonia - she is still among the students with the best academic results in her class, as was the case when she was living in Ukraine. As two new languages were added for F2's daughter after arriving in Estonia, of which Estonian was a completely new language, it is understandable why W2 is not directing her daughter to speaking Ukrainian very actively at the moment. W2 believes that it really is easier for her daughter to use Russian right now, and so she has wanted to avoid overburdening her child. As for acquiring Estonian as quickly as possible, W2 relies on Estonian as a study subject as well as on a tutor.

Contrary to F2's language ideology, F3's parents considered it necessary to enrol all three of their sons in an Estonian-language learning environment in order for them to adjust in Estonia faster. W3 emphasised that because the Estonian state has given them help and they are living in Estonia where the official language is Estonian, it is the duty of their family to know Estonian. It can be assumed that, additionally, F2's parents have a legitimate expectation that a decision in favour of an Estonian school means faster acquisition of Estonian, from which both pragmatism and attempt to meet society's expectations can be deduced (cf. Lazdina and Marten 2021). By now, the Estonian-language learning environment has started to have such a strong effect on the language practices of F3's sons that from time to time, the eldest son of F3 speaks Estonian to both his mother and to his younger brothers who are also studying at an Estonian educational institution. According to W3, the younger brothers very quickly go along with the eldest brother's use of the Estonian language. From time to time, the eldest son of F3 has admitted that he cannot remember the name of a more specific term related to the subjects in Russian, and in this case he uses Estonian. A similar tendency can also be observed in the case of the first interviewee (W1) who used several Estonian words during the interview. This is likely to have been greatly influenced by the following factors: while W1 studied in a school with Russian language of instruction, she attended an Estonian language immersion class since grade 1, she has also acquired higher education in Estonian and mostly uses Estonian at work. Thus, analysing the interview conducted with $\mathrm{W} 1$, this can easily explain why W1 uses terms from the field of education in Estonian while speaking.

In summary, in light of the information received, it is clear how quickly W3 and her children and W1 seem to have adapted linguistically to the Estonian society. For this, working language, the support of colleagues and teachers and motivation, have certainly been very important.

The second and third studied family used enrolling their children at Sunday School Nadija while W1 herself had attended the school in the past as external language management tool. W1 confirmed that she feels a lot freer in speaking Ukrainian after attending the school Nadija and, thanks to the school, knows a lot more about Ukrainian language and culture than she did before. Although W1 was proficient in Ukrainian before studying at Nadija, she emphasised that studying at the organisation 
has significantly helped her to not forget Ukrainian. According to W1, the school has also contributed a lot to the celebration of Ukrainian national holidays and knowing their background. Language managers W2 and W3 emphasised that although the shool has not influenced the choice of their home language, it has strengthened the Ukrainian identity and cultural awareness of their children. In addition, according to the newly arrived immigrant parents of the children studying at the school, Sunday School Nadija has given them a lot of new acquaintances and helped them to strengthen the sense of community among Ukrainians in Tallinn. In addition, W3 pointed out that by performing at festivals and events, other nationalities living in Estonia can also be part of the Ukrainian language and culture and learn more about Ukrainians through Nadija.

The study revealed that the head of Sunday School Nadija (A) has noticed regarding the students that 'Ukrainian and Russian seem to be competing with each other all the time for the students'. Based on previous interviews with language managers, it can be said that because some students who study at Nadija attend schools with Estonian language of instruction, the impact of Estonian is significant in terms of the scope of use and even in developing the orientation of identity, although Estonian is not their mother tongue. It could be presumed that a person is at risk of anxiety due to the competing self-perceptions or the potential feeling of splitting in two (Turner-Zwinkels et al. 2015), but the data of the current study do not confirm this. In other words, a person can have different cultural identities and be able to successfully integrate them in the majority culture without feeling split, in which the state's inclusion policy certainly plays an important role (Houtcamp 2016).

Finally, in the context of the direction of language choices and perception of identity, it is important to also mention the interplay between the identity and the digital society. Modern technical possibilities make it very easy to maintain contacts with relatives living in the country of origin, which also has a positive effect on the linguistic and ethnic identity of migrants (see e.g. Melo-Pfeifer 2015). In addition, Quinten Bernhold and Howard Giles (2017), for example, highlight encouraging frequent communication with relatives living in the home country as a fairly effective method of directing language use for children of the family. This also coincides with the results of the current study: language managers consider their own and their children's frequent communication with close relatives back in Ukraine to be extremely important. Undoubtedly, these circumstances may have a significant effect on the FLP of families (Melo-Pfeifer 2015).

In conclusion, the sociopolitical context must be taken into consideration in studying FLP as this may significantly influence the language choices of families (see also Lazdina and Marten 2021). Although the data presented above has not been used to map the FLPs of the Ukrainian community living everywhere in Estonia, these cases provide a deeper look at the issues addressed and allow initiating discussions on the sustainability of Ukrainian as one of the major minority languages in Estonia at the level of educational policy decisions. 


\section{Acknowledgements}

The research on which the article is based forms part of the doctoral thesis of the author of this article.

Address:

Elvira Küün

University of Tartu Narva College

Raekoja plats 2

Narva 20307

Estonia

E-mail: Elvira.Kuun@ut.ee

\section{References}

Bergroth, M. and Å. Palviainen (2017) "Bilingual children as policy agents: language policy and education policy in minority language medium early childhood education and care". Multilingua 36, 4, 375-399. DOI: https://doi.org/10.1515/multi-2016-0026

Bernhold, Q. and H. Giles (2017) "Grandparent-grandchild communication: a review of theoretically informed research". Journal of Intergenerational Relationships 15, 4, 368-388. DOI: https:// doi.org/10.1080/15350770.2017.1368348

Bilaniuk, L. (2005) Contested tongues: language politics and cultural correction in Ukraine. Ithaca, NY: Cornell University Press.

Bilaniuk, L. and S. Melnyk (2008) "A tense and shifting balance: bilingualism and education in Ukraine”. International Journal of Bilingual Education and Bilingualism 11, 3, 4, 340-372.

Code of ethics of Estonian researchers (2002) Estonian Academy of Sciences. Available online at $<$ https://www.etag.ee/wp-content/uploads/2013/09/Eetikakoodeks2002.pdf $>$. Accessed on 07.08.2021.

Czubinska, G. (2017) "Migration as an unconscious search for identity: some reflections on language, difference and belonging". British Journal of Psychotherapy 33, 2, 159-176. DOI: https://doi. org/10.1111/bjp.12286

Curdt-Christiansen, X. L. (2009) "Invisible and visible language planning: ideological factors in the family language policy of Chinese immigrant families in Quebec”. Language Policy 8, 351375.

Curdt-Christiansen, X. L. (2018) Family language policy. In J. W. Tollefson, M. Pérez-Milans, eds. The Oxford handbook of language policy and planning, 420-441. Oxford: Oxford University Press.

Curdt-Christiansen, X. L. and J. Huang (2020) Factors influencing family language policy. In A. C. Schalley, S. A. Eisenchlas, eds. Handbook of home language maintenance and development: social and affective factors, 174-194. Berlin and Boston: De Gruyter Mouton.

De Houwer, A. (2009) Bilingual first language acquisition. Briston: Multilingual Matters.

Duff, P. A. (2015) "Transnationalism, multilingualism, and identity". Annual Review of Applied Linguistics 35, 57-80. Cambridge University Press. DOI: https://doi.org/10.1017/ S026719051400018X 
Fogle, L. W. and K. A. King (2013) "Child agency and language policy in transnational families". Issues in Applied Linguistics 19, 1-25. DOI: https://doi.org/10.5070/L4190005288

Higgins, C. (2018) “The mesolevel of family language policy”. International Journal of Multilingualism 15, 3: Multilingual Families: Aspirations and Challenges, 306-312. DOI: https://doi.org/10.1 080/14790718.2018.1477298

Houtkamp, C. (2016) "Inclusion in the 21st century: an exploration of policy opportunities and challenges”. In Ž. Ozoliņa, ed. Societal security: inclusion - exclusion dilemma: a portrait of the Russian-speaking community in Latvia. Rīga: Zinātne, 29-43. Available online at <https:// www.szf.lu.lv/fileadmin/user_upload/szf_faili/Petnieciba/sppi/demokratija/Societal_Security_ iekslapas_20160418.pdf . Accessed on 02.08.2021.

Kaldur, K., K. Kivistik, T. Pohla, M. Veliste, N. Pertsjonok, and M. Käger (2019) Uussisserändajate kohanemine Eestis. Uuringu aruanne. [Adaptation of new immigrants. Study report.] Tartu: Baltic Research Institute. Available online at <https://www.siseministeerium.ee/sites/default/ files/uussisserandajate-kohanemine-eestis-2019-ee_1.pdf $>$. Accessed on 10.07.2021.

Kalmus, V., A. Masso, and M. Linno (2015) Kvalitatiivne sisuanalüüs. Sotsiaalse analüüsi meetodite ja metodoloogia ópibaas. [Qualitative content analysis: learning base of methods and methodology of social analysis.] Tartu: University of Tartu. Available online at $<$ https://sisu. ut.ee/samm/kvalitatiivne-sisuanalyys $>$. Accessed on 17.06.2021.

Kaveh, Y. M. (2018) "Family language policy and maintenance of Persian: the stories of Iranian immigrant families in the northeast, USA". Language Policy 17, 4, 443-477. Available at DOI: https://doi.org/10.1007/s10993-017-9444-4. Accessed on 31.08.2021.

King et al. 2008 = King, K. A., Fogle, L., and A. Logan-Terry (2008) "Family language policy". Language and Linguistics Compass 2, 5, 907-922. Available at https://doi.org/10.1111/j.1749818X.2008.00076.x. Accessed on 15.09.2021.

Kond, J. (2016) Opinions of management and support specialists on teaching new immigrants and supporting their in Estonian schools. [Juhtkonna ja tugispetsialistide arvamused uussisserändajate õpetamisest ja kohanemise toetamisest Eesti koolides.] Master's thesis Tartu: University of Tartu.

Kopeliovich, S. (2013) Happylingual: a family project for enhancing and balancing multilingual development. In M. Schwartz and A. Verschik, eds. Successful family language policy: parents, children and educators in interaction, 249-275. Dordrecht: Springer Science+Business Media. DOI:10.1007/978-94-007-7753-8_11

Kulyk, V. (2016) "Language and identity in Ukraine after Euromaidan”. Thesis Eleven 136, 1, 90-106. DOI: https://doi.org/10.1177/0725513616668621

Küün, E. (2021) "Viie ukraina juurtega pere keelepoliitika mudelid Eesti kontekstis". [Models of language policies of a families with Ukrainian roots in the Estonian context.]. Eesti Rakenduslingvistika Ühingu aastaraamat/Estonian Papers in Applied Linguistics 17, 159-176. DOI: https://doi.org/10.5128/ERYa17.09

Laherand, M.-L. (2008) Qualitative research. [Kvalitatiivne uurimisviis.] Tallinn: Infotrükk.

Lazdina, S. and H. F. Marten (2021) Why do Russian-speaking families in Latvia choose Latvianmedium education? Three narratives about critical events. In A. Verschik, ed. Multilingual practices in the Baltic countries, 240-283. (ACTA Universitatis Tallinnensis.) Tallinn: Tallinn University Press. 
Liebscher, G. and J. Dailey-O'Cain (2013) Language, space and identity in migration. The Palgrave Macmillan.

Linno, M. (2021) Kvalitatiivsed uurimismeetodid sotsiaalteadustes. [Qualitative research methods in the social sciences.] Tartu University. Available online at $<\mathrm{https} / /$ sisu.ut.ee/kvalitatiivne/ transkribeerimine $>$. Accessed on 27.08.2021.

Melo-Pfeifer, S. (2015) "The role of the family in heritage language use and learning: impact on heritage language policies". International Journal of Bilingual Education and Bilingualism 18, 1, 26-44. DOI: https://doi.org/10.1080/13670050.2013.868400

Mills, J. (2001) "Being bilingual: perspectives of third generation Asian children on language culture and identity". International Journal of Bilingual Education and Bilingualism 4, 6, 383-402.

Mills, J. (2004) "Mothers and mother tongue: Perspectives on self-construction by mothers of Pakistani heritage". In A. Pavlenko, A. Blackledge, eds. Negotiation of identities in multilingual contexts, 161-191. Clevedon: Multilingual Matters.

Padilla, A. M. and W. Perez (2003) "Acculturation, social identity, and social cognition: a new perspective". Hispanic Journal of Behavioral Sciences 25, 1, 35-55.

Palviainen, Å. and S. Boyd (2013) Unity in discourse, diversity in practice: the one person one language policy in bilingual families. In M. Schwartz, A. Verschik, eds. Successful family language policy: parents, children and educators in interaction, 223-248. Dordrecht, Heidelberg, New York, and London: Springer. DOI: https://doi.org/10.1007/978-94-007-7753-8_10

Pavlenko, A. (2004) “'Stop doing that, ja komu skazala': language choice and emotions in parent-child communication". Journal of Multilingual and Multicultural Development 25, 2-3, 179-203.

Pavlenko, A., ed. (2011) Thinking and speaking in two languages. Bristol: Multilingual Matters. DOI: https://doi.org/10.21832/9781847693389

Peräkylä, A. (2005) Analyzing talk and text. In N. K. Denzin, Y. S. Lincoln, eds. The Sage handbook of qualitative research, 869-886. Sage Publications.

Piller, I. (2001) "Private language planning: the best of both worlds?". Estudios de Sociolingüistica 2, $1,61-80$.

Rannut, Ü. and M. Rannut (2010) Tallinna õpilaste kodukeele uuring. 1. osa: vene keele mõju Tallinna opilaste kodukeelele. [Study of the home language of Tallinn pupils. Part 1: the influence of Russian on the home language of Tallinn pupils.] Tallinn: Institute for Integration Studies.

REL (2011) = Eesti Statistikaameti andmed: rahva ja eluruumide loendus 2011. [The 2011 Population and Housing Census.] Available online at $<\mathrm{https}$ ://www.stat.ee/et/statistikaamet/rahvaloendus2021/2011-aasta-rahva-ja-eluruumide-loendus $>$. Accessed on 29.07.2021.

Riigi Teataja (2014) Adaptation programm, accepted on 13.08.2014, No. 34. Available at https://www. riigiteataja.ee/akt/122082014005. Accessed on 31.07.2021.

Rothman, J. (2009) "Understanding the nature and outcomes of early bilingualism: Romance languages as heritage languages". International Journal of Bilingualism 13, 2, 155-163.

Schwartz, M. (2010) "Family language policy: core issues of an emerging field". Applied Linguistics $1,171-191$.

Seals, C. A. (2019) Choosing a mother tongue: the politics of language and identity in Ukraine. Bristol: Multilingual Matters.

Smith-Christmas, C. (2020) Child agency and home language maintenance. In A. C. Schalley, S. A. Eisenchlas, eds. Handbook of home language maintenance and development: social and affective factors, 218-236. Berlin and Boston: De Gruyter Mouton. 
Soler, J. and Zabrodskaja, A. (2017) "New spaces of 'new speaker' profiles: exploring language ideologies in transnational multilingual families". Language in Society 46, 4, 547-566. DOI: https://doi.org/10.1017/S0047404517000367

Spolsky, B. (2004) Language policy. Cambridge: Cambridge University.

Spolsky, B. (2009) Language management. Cambridge: Cambridge University Press.

Tabouret-Keller, A. (2000) “Language and identity”. In F. Conlmas, ed. The handbook of sociolinguistics, 315-326. Oxford. Blackwell Publishers.

Tammekänd, L. (2013) "Multilingualism of a Southern Estonian - comparison of Estonian, Võru and Finnish narratives". Eesti Rakenduslingvistika Ühingu aastaraamat/Estonian Papers in Applied Linguistics 9, 279-296. DOI: 10.5128/ERYa9.19

Tseng, A. (2020) Identity in home-language maintenance. In A. C. Schalley, S. A. Eisenchlas, eds. Handbook of home language maintenance and development: social and affective factors, 109130. Berlin and Boston: De Gruyter Mouton.

Tuominen, A. (1999) "Who decides the home language? A look at multilingual families". International Journal of the Sociology of Language 140, 59-76.

Turner-Zwinkels, F., T. Postmes, and M. van Zomeren (2015) “Achieving harmony among different social identities within the self-concept: the consequences of internalising a group-based philosophy of life". PLoS ONE 10, 11. DOI: https://doi.org/10.1371/journal.pone.0137879

Verschik, A. (2010) "Contacts of Russian in the post-Soviet space". In Li Wei, ed. Applied Linguistics Review 1, 85-127. De Gruyter Mouton

Verschik, A. and C. J. Doyle (2017) "Young Swedish-Estonian returnees to Estonia: reflections on family language policy and a multilingual upbringing”. In M. Siiner, K. Koreinik, and K. Brown, eds. Language policy beyond the state, 123-140. (Language Policy, 14.) Cham: Springer. DOI: https://doi.org/10.1007/978-3-319-52993-6_7

Wilson, S. (2019) "Family language policy through the eyes of bilingual children: the case of French heritage speakers in the UK". Journal of Multilingual and Multicultural Development 41, 3, 1-19. DOI: $10.1080 / 01434632.2019 .1595633$

Wilson, S. (2020) Family language policy. Children's perspectives. Milton Keynes, UK: Palgrave Macmillan. DOI: https://doi.org/10.1007/978/-3-030-52437-1

Õunapuu, L. (2014) Kvalitatiivne ja kvantitatiivne uurimisviis sotsiaalteadustes. [Qualitative and quantitative research in the social sciences.] Tartu: University of Tartu. Available online at $<$ http://hdl.handle.net/10062/36419>. Accessed on 20.08.2021.

Yin, R. K. (2009) Case study research: design and methods. 4th ed. Thousand Oaks, CA: Sage. DOI: https://doi.org/10.33524/cjar.v14i1.73 